MARINKO JURČEVIĆ, Ph.D.

E-mail: marinko.jurcevic@fpz.hr

University of Zagreb,

Faculty of Transport and Traffic Sciences

Vukelićeva 4, HR-10000 Zagreb, Republic of Croatia

FRANE MITROVIĆ, Ph.D.

E-mail: fmitrov@pfst.hr

MILA NADRLANSKI, Ph.D.

E-mail: mila@pfst.hr

University of Split, Faculty of Maritime Studies

Zrinsko-Frankopanska 38, HR-21000 Split,

Republic of Croatia
Transportation Economy

Preliminary Communication

Accepted: Apr. 20, 2010

Approved: Oct. 28, 2010

\title{
SYSTEM DYNAMICS AND THEORY OF CHAOS IN FREIGHT RATE FORMING IN SHIPPING
}

\begin{abstract}
This paper deals with the application of System dynamics and Chaos theory in shipping using the example of freight rate forming. The development of new technologies, changes in structure and conditions, information accessibility, etc. are only some of the factors that intensify changes in freight rate forming in shipping. Therefore, shipping environment is becoming increasingly complex and dynamic. System dynamics seems to be a tool very suited for modelling of strategic and operational behaviour in shipping business. Due to the complex behaviour of these systems, chaos theory can also help in modelling of processes in shipping. The basic feature of chaotic systems is fine sensitivity in conditions at the beginning, when small change in input value may cause great changes in output values. By applying its concepts to the business process, as well as in freight rate forming in shipping, it prepares the business systems for quick response to the changes in the environment.
\end{abstract}

\section{KEY WORDS}

chaos theory, shipping, freight rate, system dynamics

\section{INTRODUCTION}

Freight rate is a shipping fee paid to a shipper/ charterer for their transport services. In other words, it is a price of maritime freight transportation services. In the maritime transport freight is always related to the structure of the maritime market and particular relations of supply and demand in it. Therefore, freight rate is primarily a market price which, depending on the degree of market competitiveness, is expressed as a competitive or monopolistic one. The impact of administration or planning on freight rate in overseas transport is almost negligible. Concerning this, each individual shipper should continually adapt their own shipping capacity to freight rate movements in the market. During the time of freight rate increase, individual shipper/charterer increases their offer of transport capacity (in the short period by increasing the ship speed, reducing ship retention in ports, better and more rational stowage, by activating laid-up ships and building new vessels). During the time of freight rate decrease they reduce their offer in the market by reducing the ship speed at sea and putting less effective ships into lay-up.

In the shipping business, freight rates are the only profit of ship-owners and are therefore extremely important. Freight rate forming is a very complex process as it is obvious now in the time of global financial crisis. The banks do not give credentials and credits which brings to depletion in good trade flow and apparition of excess in ship tonnage. The freight rates can drop up to $90 \%$ in extremely short period of time. The development of new technologies, change in the structure and conditions of shipping business, information accessibility, etc., are also some of the factors that intensify changes in freight rate forming in shipping. Therefore, shipping environment is becoming increasingly complex and dynamic. Time and information are key factor for successfulness of the business process and therefore of the shipping business as well. The business system must be able to anticipate what will happen next, in order to respond quickly and efficiently to the changes in the environment. Five years ago, it was relatively easy to predict the desired results of freight rate increase. But today this is more difficult due to the financial crisis and complexity of ship market. It is necessary to redefine 
the traditional concepts of control and to invent new ones. The knowledge of Chaos theory as well as System dynamics theory gives great and original contribution to the shipping.

\section{SYSTEM DYNAMICS THEORY}

System dynamics was considered as managerial discipline because the systems studied first were the business ones. The originator of this method was Jay Forrester. As a manager of various projects and a member of management in different companies, he observed that the base obstructions for company progress did not come from the method or the means of work but rather from politics and the decisions made by the management. Management is a cyclic process in which the decision results from change, and change again influences the decisions that are to be made later. It is important to notice that System dynamics has a great role in the process of understanding how various politics can influence the system, because it enables the design of computer models that simulate the system. The use of models in exploration of certain systems stimulated Forrester and his followers to research dynamic systems other than the business ones.

System dynamics combines theory, philosophy and methods for analysis and management of complex systems with feedback loops. Feedback loop means that an activity $F$ influences activity $M$ which again influences $\mathrm{F}$ etc. It is important to observe the connection between $\mathrm{F}$ and $\mathrm{M}$ independently and linearly, as well as the connection between $\mathrm{M}$ and $\mathrm{F}$, but it is also necessary to observe the whole system as the integral system in order to predict the behaviour of the system. The world is not linear. We live in an environment in which we make decisions upon the state of the system. The decisions cause changes and lead to a new state upon which we make new decisions. It can be presented as in Figure 1.

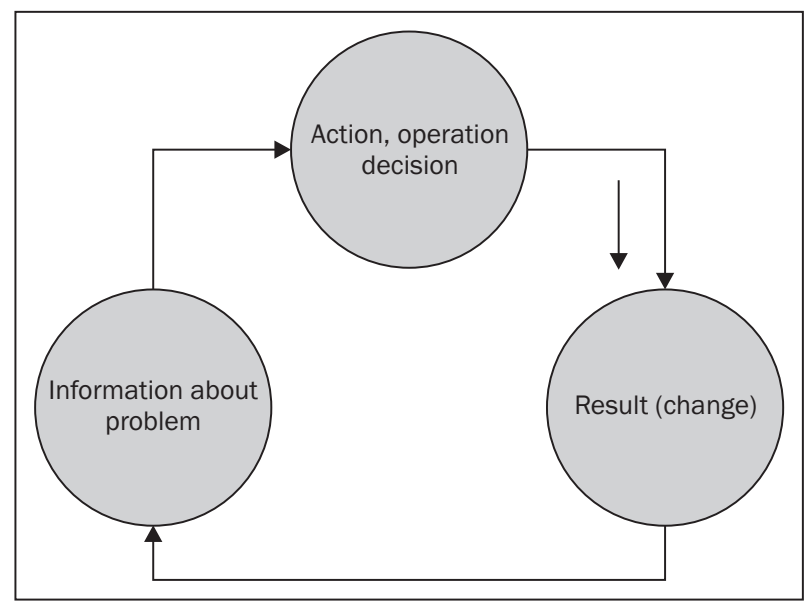

Figure 1 - Cyclic feedback loop
System dynamics as a methodology is based upon the creation of models for dynamic systems. The creation of the models has the following steps:

- problem identification - defining the point for system observation, defining the system limit, aim of model, etc.;

- system conceptualization - determination of the elements and the structure of the system, diagram making, setting dynamical hypotheses that explain the cause of the problem;

- model formalisation - building computer-simulated model that presents the essence of the problem;

- analysis of model behaviour - testing of model behaviour that has to follow the behaviour of the real system;

- evaluation and validation of the model as well as testing of alternative problem solutions;

- models application. $^{1}$

System dynamics is a method developed for better understanding of systems and for controlling the factors that cause changes in the systems.

\subsection{Problem identification and system conceptualization}

System dynamics is based on the System Thinking concept. System Thinking enables observation of the system structures, so that the system behaviour can be understood, but it does not imply building of the model. The system structure includes four hierarchical components:

- System limits - limits have to be defined so as to include only those elements that cause certain system behaviour.

- Cyclic feedback loop as basic system presentation - system behaviour is defined by the element structure in the closed loop; feedback loop is responsible for changes in the structure during the course of time.

- Levels and rates - within system there are levels or states and rates or changes of state. Levels or states present the quantity of an element, e.g. number of employees, and the level of water in the water tank, etc. rates present the unit of change of state (increasing or decreasing of level).

- Aims, observed state, disharmony between aims and conditions, wanted action - aim is the system state that can be achieved through the change, and observed state is the state at that specific moment of the system. Disharmony between the two states leads to action in order to decrease discrepancy between them.

System structure can be graphically presented with two types of diagrams:

- Casual Loop Diagram/Feedback Diagram,

- Stock/Flow Diagram. 


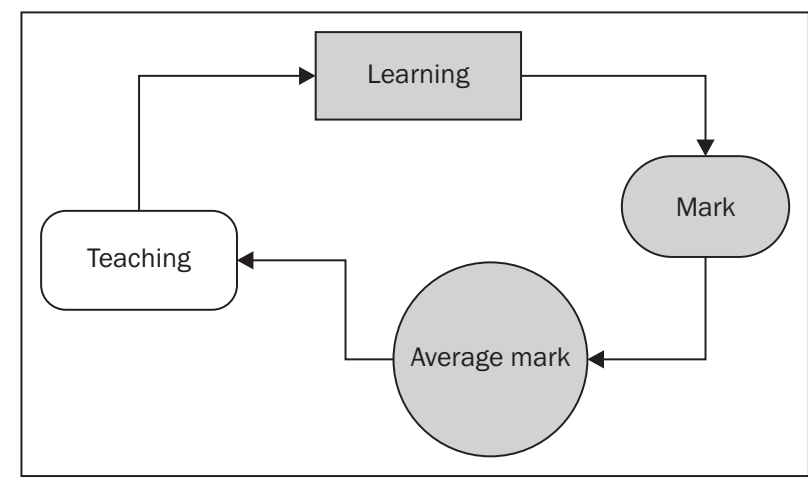

Figure 2 - Feedback loop in teaching

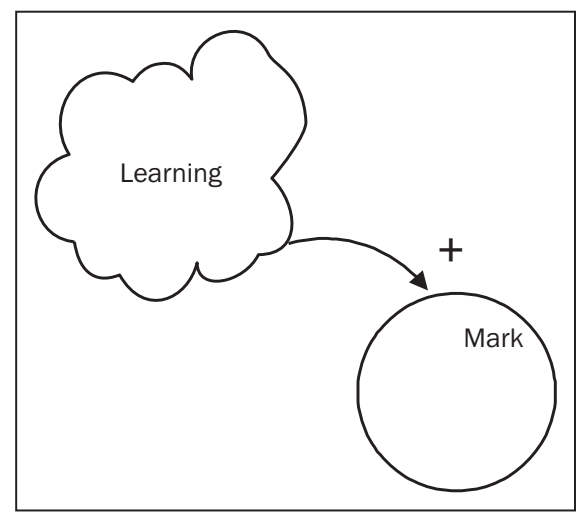

Figure 3 - Positive feedback loop

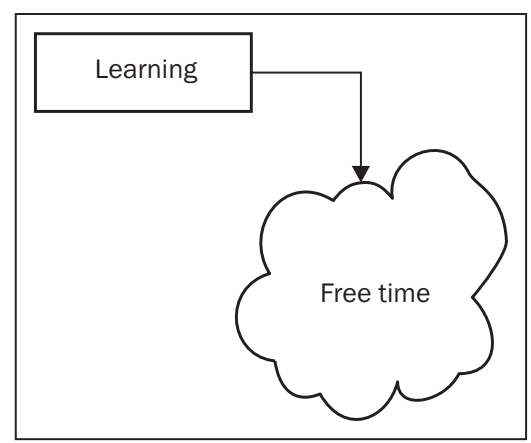

Figure 4 - Negative feedback loop

Casual Loop Diagram/Feedback Diagram presents cyclic cause-consequence feedback loop. Cause leads to consequence that influences cause etc.

\subsection{Computer-simulated models}

When people consider various occurrences of the real world, they form mental models about those occurrences. System dynamics enables formalisation of mental models of dynamic systems by creating computer-simulated models. Transformation of mental model into computer-simulated model enables easier disclosing, learning and comprehending of the system structure. The model reflects the system behaviour on the basis of given system variables. It is possible to change the system structure by changing the system variables and to analyze the system during the course of time. These simulations enable modelling of the system which is otherwise difficult or impossible to follow in the real world (e.g. ecosystem change over a long period of time or in a remote geographical region). Good computer-simulated model has to show how and why a dynamic process behaves in a certain way at a certain moment. The computer-simulated model is efficient if it improves the mental model of a real system.

\section{CHAOS THEORY}

Chaos theory was originally developed in natural sciences, first in the field of physics and meteorology, and then in biology, chemistry and medicine. In the last decade it was also applied in the field of organisation and education. It is a multidisciplinary science that changes the way of observing and comprehending the world, discovers new rules and universal behaviours that cross the limits of various scientific fields. The systems studied in the chaos theory are unpredictable and seemingly chaotic (with no rules). The central concept in the chaos theory is the determination of the behaviour of the whole system, instead of determination of one precise state of the system. The systems too complex for traditional mathematics can be studied by simple laws, e.g. fractal geometry and fuzzy logic. Complexities laws depend on hierarchic scale (scalar, self resemblance) and they are not caused by the behaviour of constituting parts. It is less probable that one can explain the behaviour of the parts by the behaviour of the whole system. Analysing of nonlinear system behaviour is like walking through a labyrinth with moving walls at every step (the game is changing during the course of playing). The basic feature of chaotic systems is fine sensitivity in conditions at the beginning, when small change in input value may cause great changes in output values. In literature, this is known as Butterfly Effect ("A butterfly flapping its wings in China might change the weather in Europe“) [1].

There are two substantial elements in determination of the chaos; attractors and fractals. Attractors present an area in the field of results toward which the system dynamics is directed. Attractors enable transforming unexpected data into noticeable data, i.e. they present the result model of system behaviour. Their size and form depend on key parameters and the dynamics toward the system is directed by those parameters. The key parameter is any factor influencing the system behaviour. The most famous attractor is Loren's attractor (Figure 5).

When the Chaos theory is used in the social context, three attractors can be explained with the following:

- Dotted attractors (dichotomy/one-way direction) present behaviour of social beings in search for 


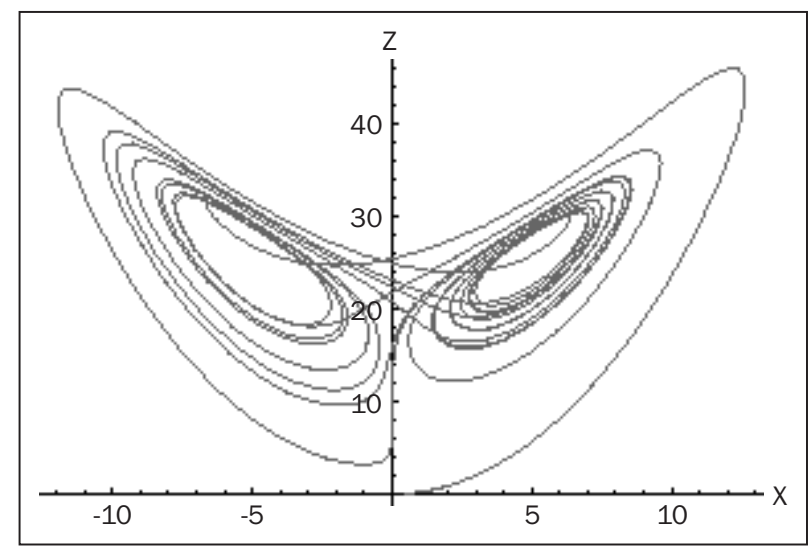

Figure 5 - Lorens attractor

their natural instincts (fear, love, desire for division or self-interest).

- Cyclic attractors (dialectic/self-preserved) would refer to the principle of multidimensionality, search for opposite but complementary tendencies: stability and change, safety and freedom, and even differentiation and integration. Cyclic or periodic emphasis is the result of suboptimisation from one orientation to another. ${ }^{2}$

- Torus attractors (equally final/negative entropic/ aim searchers) reflect the behaviour of the social culture systems with the choice of outcomes and means; unpredictable patterns come out of stylistic aptitudes of appropriate factors.

Another important element is fractal, which is defined as irregular geometrical form. Fractals are significant for the chaos theory, because the behaviour of the chaotic systems is founded on fractal geometry which is in contrast to the traditional Euclid's geometry. Fractal geometry deals with the description of irregular form in nature that is more frequent than regular and linear forms.

Significant fractal characteristic is its self-resemblance that indicates that fractal will look identically regardless of the size or proportion. Figure 6 presents the fractal form of snow crystal.

Fractals are used for organizational structure forming. A new form of organization called fractal organization is already known in literature. It is one of sub- stantial forms of business adjustment to changes in the environment. The question of significance of the chaos theory is often raised for business processes, especially how the theory, whose origins are based on physical systems, can be applied in business systems. The chaos theory in fact raises the question of traditional ways of understanding and business control. According to that concept freight rate forming is a system that requires unyielding check-up. The application of the chaos theory in freight rate forming would not remain on pure assumptions. The freight rate characteristics identified by chaos researchers and practitioners are analogous to the ones in complex physical systems:

1. Non-linearity,

2. Non-predictability,

3. Interdependency,

4. Synergetic behaviour,

5. Autopoesis,

6. Limits,

7. Reversed connections,

8. Self organisation ${ }^{3}$.

They enable the application of the chaos theory in business systems.

\section{THEORY OF SHIP PRICE}

A summary of the main features of the theory of ship price is given here. It is assumed that vessel owners maximize profits under conditions of perfect competition. They are price-takers on freight rates $(F R)$ as well as voyage costs ( $P C$, bunkers, wages, and port charges). The number of voyages depends on the average speed of the vessel $(N)$ and voyage costs depend on the speed of the vessel. The profit from the vessel is:

$\Sigma=N F R-N^{n} P C-C O, n>1$

where $N^{n}$ is the relationship between voyage costs and speed, and $\mathrm{CO}$ are fixed costs. The optimal speed of the vessel can be implied by maximizing $\Sigma$ with respect to $N$ :

$N=(F R / n P C)^{1(n-1)}$

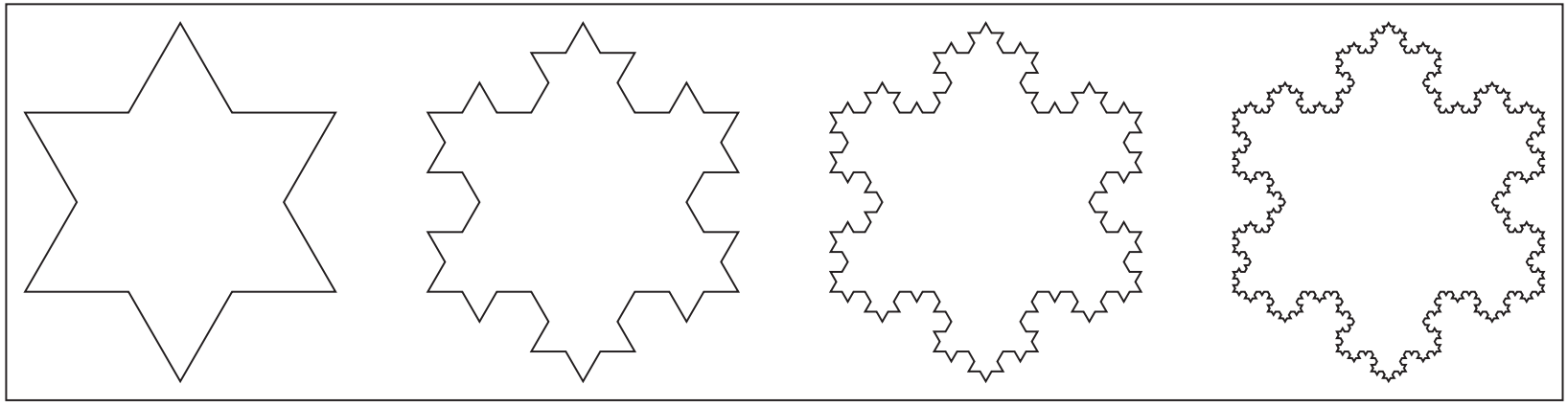

Figure 6 - Fractal appearance 
Speed depends on the ratio of freight rates to voyage costs. When speed is optimal the profit is: $F R^{n /(n-1)} n^{1 /(1-n)}$

Freight rates are determined by demand and supply in the freight market. Supply depends on the trading fleet times its average speed. An average speed depends on the ratio of freight rates to voyage costs. The fuel consumption depends on the speed. The optimal speed varies with bunker prices. Higher port charges increase the incentive to operate on the high seas instead of being anchored at port. The trading fleet excludes ships that are laid-up but includes combined carriers operating in the dry cargo market.

Lay-up depends on freight rates, voyage costs and running costs relative to lay-up costs. The fleet size varies because of shipbuilding and scrapping. Shipbuilding varies directly with the price of ship and scrapping varies inversely with ship price. The stock demand for ship as capital assets varies directly with the expected relative rate of return, that depends upon expected operating profits on vessels, the expected capital gain on ships and competing returns to wealth. In the short run the second-hand price of ship is determined on the capital asset market for ships, i.e. the stock demand equals the stock supply which changes over time as described. Since the size of the fleet affects freight rates while freight rates affect the stock demand for vessels, freight rates, ship prices and fleet size are dynamically interdependent.

Shipping market is extremely dynamic and can be presented as a chaotic process by its nature.

\section{DISCUSSION}

Traffic is defined as a complex dynamic system with a large number of elements of the internal structure and subsystems which characterize it in its dynamic development, but also give it the characteristics of traffic as a whole. Traffic system needs a fundamental change in the concept of organization in order to achieve the desired goals. Attention will be mostly focused on freight issues in the maritime economy and on its importance in the economic structure. The complexity and dynamics of technical and social phenomena have been noticed in marine long ago, but their implication within the traditional methodology has always been a serious challenge for researchers. The perspective of theory of dynamic systems, although relatively new in the research of maritime economics, as well as in other maritime sectors, provides an opportunity for elaborate analysing the phenomena which cannot be analysed by traditional methodologies. This article describes the concepts of the theory of dynamical systems, as well as examples of their usage in ship freight. Freight rate is an economic category which shows the current situation in the shipping business concerning supply and demand.

The identification of key parameters directing system from one dynamic state into another is very important. It is also important to take care of unpredicted situations and to support assimilation of flexible strategies. It is considerably important to emphasize that the modification of business aims has to be anticipated, so it does not cause shocks and surprises. In the process of management some rules, substantial for chaotic systems, have to be followed:

- Managers have to pay attention to communication at all levels;

- Small changes can cause big effects in chaotic conditions;

- Unanticipated and unexpected characteristics have to be expected.

Substantial characteristics of management in chaotic conditions are early identification of events and quick application of response which is the mixture of strategy and acceptance of the uncertainty.

\section{CONCLUSION}

Nowadays, the knowledge of the Chaos theory as well as of the System dynamics theory, give great and original contribution to shipping. System dynamics seems to be a tool very suited for modelling of strategic and operational behaviour in shipping business. Computer-simulated models enable modelling of a system which is otherwise difficult or impossible to follow in the real world. Understanding the system dynamics enables consideration of the actions and the resulting consequences. Chaos theory enables better understanding of operations of organisation. By applying its concepts to the business process, and freight rate forming in shipping as well, it prepares the business systems for quick response to the changes in the environment.

The purpose of this paper has been to emphasize the importance of the economic aspect of the traffic function and position of the freight in the economy, as well as its positive and negative aspects. It can be concluded that freight rate is an economic category which can increase shipping capacity and affect ship's departure to ship-breaking yard, or to a lay-up. 
Dr. SC. MARINKO JURČEVIĆ

E-mail: marinko.jurcevic@fpz.hr

Sveučilište u Zagrebu, Fakultet prometnih znanosti

Vukelićeva 4, 10000 Zagreb, Republika Hrvatska

Dr. Sc. FRANE MITROVIĆ

E-mail: fmitrov@pfst.hr

Dr. Sc. MILA NADRLJANSKI

E-mail: mila@pfst.hr

Sveučilište u Splitu, Pomorski fakultet

Zrinsko-Frankopanska 38, 21000 Split, Republika Hrvatska

\section{SAŽETAK}

\section{SISTEMSKA DINAMIKA I TEORIJA KAOSA U FORMIRANJU VOZARINA U BRODARSTVU}

U ovom se radu razmatra primjena sistemske dinamike i teorije kaosa u brodarstvu na primjeru formiranja vozarina. Razvoj novih tehnologija, promjene struktura i uvjeta, dostupnosti informacija, itd. samo su neki od čimbenika koji intenziviraju promjene $u$ formiranju vozarina $u$ brodarstvu. Zbog toga brodarstvo postaje sve kompleksnije i dinamičnije. Sistemska se dinamika čini dobrim alatom za modeliranje strategija i operacijskih ponašanja u brodarstvu. Teorija kaosa također može biti od pomoći u modeliranju procesa u brodarstvu jer je ponašanje ovih sustava vrlo složeno. Osnovna karakteristika kaotičnih sustava je fina osjetljivost na uvjete u početku, kada male promjene u ulaznim vrijednostima mogu uzrokovati velike promjene izlaznih vrijednosti. Primjenom ovih koncepata na poslovne procese i formiranje vozarina u brodarstvu pripremaju se poslovni sustavi na brz odgovor na promjene u okolini.

\section{KLUČNE RIJEČI}

brodarstvo, vozarine, sistemska dinamika, teorija kaosa

\section{REFERENCES}

1. Nadrljanski, Đ., Nadrljanski M.; Kibernetika u obrazovanju, Sombor 2005, p. 55.

2. Nadrljanski, Đ., Nadrljanski M.; Kibernetika u obrazovanju, Sombor 2005, p.52.

3. Nadrljanski, Đ., Nadrljanski M.; Kibernetika u obrazovanju, Sombor 2005, p.53.

4. Nadrljanski, Đ., Nadrljanski M.; Kibernetika u obrazovanju, Sombor 2005, p.61.

5. Formulas were modified by Prof.dr.sc. F. Mitrović

\section{LITERATURE}

[1] Nadrljanski, Đ., Nadrljanski M.; Kibernetika u obrazovanju (Cybernetics in Education), Sombor 2005. ISBN 86-83097-46-3

[2] Adland, R., Jia, H., Lu, J.: Price dynamics in the market for LPG transport, Energy Economics, 30, 2007

[3] Beenstock, M., Vergottis, A.: An econometric model of the world market for dry cargo freight and shipping, Applied Economics, 21, 1989

[4] Engelen, S., Meersman, H., Van der Voorde, E.: Using system dynamics in maritime economics, Maritime Policy Management, 33 (2), 2006

[5] Martin, F. F.: Computer Modeling and Simulation, New York Wiley, 1968

[6] Mihram, G. A.: The Modeling Process IEEE Transactions on Systems, Man and Cybernetics, SMC-2, 1972

[7] Stevens, J.D.: Leading the way in $21^{\text {st }}$ century, http:// www.alliancetp.com/archive/enerprise/041598_qanda-content.html 